\title{
Gold nanoparticles synthesis to application as nano biosensors
}

\author{
Jairo Pinto Oliveira" ${ }^{*}$, Adilson Ribeiro Prado, Bárbara Altoé Milaneze, Wanderson Juvêncio Keijok', Dominik Lenz², \\ Josimar Ribeiro ${ }^{1}$, Moises Renato Nunes Ribeiro ${ }^{1}$, Maria José Pontes ${ }^{1}$, Breno Valentim Nogueira', \\ Marco Cesar Cunegundes Guimaraes ${ }^{1}$
}

From 5th Congress of the Brazilian Biotechnology Society (SBBIOTEC)

Florianópolis, Brazil. 10-14 November 2013

\section{Background}

The particularities of gold nanoparticles (AuNP's) have stimulated different areas of research in recent years. The exploitation of the optical properties, electronic and magnetic materials has allowed these his job in different fields of application, such as the construction of biosensors in gradual release system for drugs, lubricants, solar cells, catalysis and other [1].

The properties of the nanoparticles are dependent on the size and shape of the particles. The same material composition can be determined with different physical and chemical characteristics just modifying characteristics such as size, self-organization, crystalline structure and shape, the point of the material in the nanometer range show distinct physical and chemical properties of materials on the macroscopic scale [2].

The aim of this work was to optimize the synthesis of gold nanoparticles using the reduction method sodium citrate, assessing concentrations of this reducing agent and the synthesis time. The attempt is to develop a route to generate nanoparticles from a precursor and facilitate the use of these nanomaterials in biosensors.

\section{Methods}

To check the effect of variables on conversion of the reaction, as well as finding the conditions that maximized the synthesis of nanoparticles, one factorial design $\left(3^{2}\right)$ with 3 levels and 2 variables was performed. The variables evaluated were: Concentration of Reducing Agent (1.0, 2.0 and $3.0 \%$ ) and the time synthesis (5, 10 and $15 \mathrm{~min})$. These intervals were defined to cover most of the studies described in the literature [3].

${ }^{1}$ Universidade Federal do Espírito Santo (UFES), Vítoria, ES, Brazil

Full list of author information is available at the end of the article
To prepare the AuNP's, the reducing agent (sodium citrate $-\mathrm{Na}_{3} \mathrm{C}_{6} \mathrm{H}_{5} \mathrm{O}_{7}$ ) was added under experimental design to the precursor solution gold $\left(\mathrm{HAuCl}_{4} 2.5 \times 10^{-4}\right.$ $\mathrm{M})$ at $65^{\circ} \mathrm{C}$ and was maintained under stirring for the time evaluated.

AuNP's samples were collected after the synthesis step and had their optical properties assessed by spectrophotometry UV-visible (SHIMADZU). The size and morphology of AuNP's were examined by transmission electron microscopy (JEM-1400, JEOL Inc, USA).

\section{Results and conclusions}

Results were obtained from the spectra of the solutions in electronics and suspension compared with the images of transmission electron microscopy, which showed the difference in particle size.

Surface charts were generated in order to optimize the results and Pareto was introduced to allow better visualization and identification of variables and interactions that affect the synthesis of gold nanoparticles $(\mathrm{p}<0,05)$.

The two variables were significant in the process and higher absorbance were found in greater synthesis times. It was concluded that the reducing agent acts as a stabilizer evaluated, since in higher concentrations there is a decrease in absorbance and thus, the smaller the size of the nanoparticles.

\section{Acknowledgements}

Brazilian Ministry of Science and Technology (CNPq Grant 483036/2011-0), The Education Ministry (MEC-PROEXT Grant 04/2011) and The Ministry of Science and Technology (MCTI/FINEP/CT-INFRA grant PROINFRA 01/2006).

\section{Authors' details \\ 'Universidade Federal do Espírito Santo (UFES), Vítoria, ES, Brazil. \\ ${ }^{2}$ Universidade Vila Velha (UM), Vila Velha, ES, Brazil.}




\section{References}

1. Page K, Proffen T, Terrones H, Terrones M, Lee L, Yang Y, Stemmer S, Seshadri R, Cheetham A K: Direct observation of the structure of gold nanoparticles by total scattering powder neutron diffraction. Chem Phys Lett 2004, 393:385-388.

2. Morones JR, Elechiguerra JL, Camacho A, Holt K, Kouri JB, Yacaman MJ: The bactericidal effect of silver Nanoparticles. Nanotechnology 2005, 16:2346.

3. Krishnendu S, Sarit SA, Chaekyu K, Xiaoning L, Vincent MR: Gold

Nanoparticles in Chemical and Biological Sensing. American Chemical Society Chem Rev 2012, 112:2739-2779.

doi:10.1186/1753-6561-8-S4-P249

Cite this article as: Oliveira et al:: Gold nanoparticles synthesis to

application as nano biosensors. BMC Proceedings 2014 8(Suppl 4):P249.

Submit your next manuscript to BioMed Central and take full advantage of:

- Convenient online submission

- Thorough peer review

- No space constraints or color figure charges

- Immediate publication on acceptance

- Inclusion in PubMed, CAS, Scopus and Google Scholar

- Research which is freely available for redistribution

Submit your manuscript at www.biomedcentral.com/submit
C Biomed Central 